ment of the bladder, submucous extravasation of blood, and enlargement of the prostate gland, may all occasion impediments.

4. It is erroneous to suppose that the peritoneum tolerates the presence of pent-up urine. The idea of tolerance appears to have originated partly from the fact that post-mortem examinations of cases of ruptured bladder sometimes detect very slight, if any, traces of peritonitis, and partly on cases which appear to indicate the ability of the peritoneum to absorb effused urine. The basis will not support the superstructure. For if the history and progress of the cases in which patbological peritoni is was absent be examined, all the symptoms of intense irritation and inflammation of the peritoneum will be found, and the issue was death. The presence of absence of lymph, as evidence of inflammation and irritation or the contrary, is little to the purpose. Purulent collentions or serous exudation may take the place of ly mph, and evidently the tolerance of urine by the peritoneum must be judged not merely by the effusion of lymph, but by the local and general symptoms and by the issue of the case. If the intrusion of urine into the peritoneal cavity produces intense pain, tenderness, and distension of the abdomen, and if these symptoms are accompanied by constant vomiting, restlessness, a sunken anxious countenance, altered temperature, feeble pulse, hurried respiration, clammy sweats and intense prostration, terminating in death, I cannot understand why it should be affirmed that the peritoneum tolerates the presence of pent-up urine because after death it is sometimes found to have retained its smooth glistening aspect, and to be free from undue vascularity, adhesions, and lymph. That the peritoneum may absorb urine effused into its cavity I will not dispute, though $I$ believe that this absorption is slight. But even if it takes place in any quantity, as conjectured by Solly, Le Gros Clark, Max Bartels and others, I entertain no doubt whatever that it exercises a most depressing influence upon the system of the patient, so that the matter may be summed up in this way : However tolerant of urine the peritoneum may appear in some cases of ruptured bladder, intolerance of it is plainly exhibited by the system of the patient. Nor is urine tolerated in the areolar tissue, be it the urine of the infant or the urine of the adult. Both alike, when pent-up in the meshes of the tissue, will set up inflammation, suppuration and sloughing, and I distrust altogether any statements which would involve any opposite conclusion.

\section{A SCHEME FOR THE MORE COMPREHENSIVE STUDY AND PREVENTION OF SO-CALLED ZYMOTIC DISEASES.}

\section{BY THOMAS M. DOLAN, F.R.C.S. EdIN.}

\section{Provisional Outuine.}

THE theory of creative evolution has placed the study of the genesis of species on a scientific basis. The germ theory promises as much for medicine. A richer fruition will result if the germ theory be studied by the light of evolution. We have seen its application in the animal and regetable world; it has been extended to the sociological aspects of life, \&c. It may be applied with ad. vantage to the study of disease. Disease is not an entity standing alone. It should always be considered in its relation to the cosmos. Buckle, in his "History of Civilisation," vol. iii., p. 447, tells us that the great glory of Hunter as a pathologist was that he formed the grand conception of a universal pathology. Buckle says: "With him [Hunter] the science of pathology did not mean the laws of disease in man alone, or even in all animals, or even in the whole organic kingdom; but it meant the laws of disease and of malformation in the entire material world, organic and inorganic. His great object was to raise a science of the abnormal. He determined to contemplate nature as a vast and complicated whole, exhibiting indeed at different times different appearances, but preserving amidst every change a priaciple of uniform and uninterrupted order, admitting of no deviation, undergoing no disturbance, and presenting no real irregularity." In the views herein set forth there is then nothing new, except perhaps in the method in which they are set forth. It is one which has occurred to many minds. There is a tendency at the present time to consider disease in its relation to evolution. The papers by Dr. Airy, Dr. Roberts, SurgeonGeneral Gordon, and Mr. Millican indicate the direction in which this current is setting. The principal zymotic diseases are small-pox, scarlatina, mea les, whouping-cough, diphtheria, cholera, and typhoid. We have evidence to support the view that these diseases are caused by micro. organisms. These diseases must be studied in the same way that the naturalist studies animals and plants. The naturalist, when engaged in the study of the life-history of any individual animal or plant, looks in a broad-wor'd point of view at his subject, and by the aid of evolution throws light on the genesis, distribution, development, transmutation, and varieties of each animal and plant. The scientific physician must approach the study of disease in the same way.

The following is an outline of what I believe should be done :-

1. The Genesis of Contagium Vivum.--Under this head will be included the life-history of each form, tracing it as far back as possible. Evolution does not tell us when each seed, as, for instance, that of the oak or the ach, first appeared. We can only go as far back as the historical period extends ; so we cannot expect to be able to reach the ultimate stage when each disease first appeared. Evolution fixes in what part of the globe each plant examined first appeared, as the scientist not only traces back to the earliest period its existence, but also, by the study of its habits, is able to determine the zone in which it could exist. As regards the gene-is of each individual disease germ we must apply the general principles of evolution.

2. Reprocluction. - Under this head will be considered the mode of reproduction, whether slow or rapid, whether the seeds are derived from seed forms, or whether multiplication takes place by fission. Example: Drs Dallinger and Drysdale's experiments on the life-history of some monads. These ohservations are models of what is wanted.

3. Development, Maturity, and Decay.-Duration of life in each form of contagium. How long may it be preserved? Average period of existence in mature and embryonic form. Morphology and physiology.

4. Laus Controlling Contagia, \&e. - Special seasons of activity; the iufluence of environmert on each disease; sanitary conditions and relation to physical phenomena; influence of oxygen in the atmosphere; heredity, variations; crossing or transmutation; susceptibility; relation of the hahitat; progressive development of types; application of a calogy of laws regulating plant life.

5. Distribution in its Geographical Relations.-Influence of climate; atmospberic variations; warmth, moisture, winds barometric, electric, thermic disturhauce, \&c. Secondary natural influences; currents; winds; animals, transport by. Effects of human interference. Example: Neasles introduced into Fiji Islands. Migrations. Effects of cultivation by civilisation. Effects of extinction of diseases by sanitation, similar to extinction of weeds in the plant world. Distribution of disease in zones. Ritlation of disease to flora and fauna. Natural selection for lucalities. Latitudes in which diseases are found. General method of diffusion.

6. Geological Distribution. - Nature of soil, subsoil, alluvium, clay, \&c. ; rock. Mountain, valley, or plain; drainage; swamps; watershed; rivers; lakes.

\section{General Preventive Measures,}

These can only be secured by establishing, as it were, a sanitary cordon round the world, and by the combined inve-tigation of disease by an international method, London, Paris, Berlin, Vienna, Brussels, \&c., to be in communication, so that the heads of sanitary bureaux in each country may know the sanitary state of each country. This could be done by maps, charts, and records, to be framed and kept on a uniform plan. The incidence of disease in individuals and communities will be noted sex, age, colour, nationality will have their proper place assigned; sporadic, endemic, and epidemic states will be considered in relation to causation. Hygiene will thus be carried out in a cosmic spirit; all those minor consideritions as trades and professions will be examined in their relation to disease; whilst the value of food, pure air. water, \&c., will be also appraised.

Vast statistics on almost every point connected with disease will by these means be secured, and conclusions drawn 
therefrom. Thus will be obtained the sum of the conditions of the causes and propa.yation of disease ; thus will be found the varring effects of climate and other agencies; and, above all, we shail letrn the value of preventive measures necessary for its eradication. We have not as yet in England arrived at an appreciation of some of the simplest elementary truths in reference to prevention ; for instance, the notification of infectious diseases and hospital accommodation for them are two of the first essentials. They should be State regulations. Each town is now allowed local option as to what it shall do. It seems Quixotic to attempt a broader scheme in the face of the prevailing indifference or disregard for both these measures in England. Prevention and spread of disease are not only $S$ ate questions, but they hare a cosmopoli an interest. Now that communication between different countries is so rapid and so much facilitated by steam, the healih of one country is of vital interest to all countries; causes operating in England may affect France

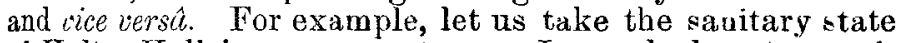
of Hull. Hull is a seaport town. Let us look at the sanitary state of this town in the year 1881. In consequence of the preval nce of scarlatina the Lncal Government Board sent down Dr. Airy to inquire into the sanitary condition of the town. Dr. Airy held the inquiry on the 9th and 10th of Narch. The medical profession of the town submitted a memorial from which I extract a few items. The memorial sets forth that the outfalls of the sewers are blocked for sixteen hours out of the twenty-four, and that the ventilation of the sewers is most defective. The present mode of collection of niubt soil is very ineficient, being effected irregularly in open carts. Refuse is deposited in various parts of the town on unused plots of ground. The connexion of houses with the main drainage is notoriously insufficient. New houses are not examined duriug the course of erection as to their drainage and other sanitary arrangementa, and building sites are frequently formed by the filling up of disused brickponds with animal and vegetable refuse and street scrapings. The Artisans and Lahourers' Dwellings Act and the Sale of Food and Drugs Act are not properly carried out, nor are the sections of the Public Health Act dealing with offensive trades and the smoke nuisance. A reserroir supplying water to the town is uncovered, though exposed to the foul emanations issuing from fish and bone manure works in close proximity. The hospital accommodation for cases of infectious disease occurring in the trown is totally inadequate, especially in view of the special davger to Hull arising from its close and frequent communication with the Continent. Disinfection is not undertaken by the local authorities free of expense, and the charges which the Corporation make no doubt deter many people from having their disinfection properly done. There is no mortuary in the town, and the means adopted for the prevention of epidemics are generally inadequate. This is a sad picture in the nineteenth ceutuy. Hull in this insanitary condition is a danger to the world. She may distribute scarlatina by ships as well as wind and wave currents. At present health officers of different countries are ignorant of the general sanitary state of other countries. Under my system the state of Hull would be known. . Perhaps a friendly communication might be made by some foreign State to the Minister of Pablic Health in England to look after the sanitary state of Hull if this in eruational system were at work.

My leading ideas are-1. That the sanitary authorities of each country should work on one uniform plan and under central direction. 2. That all sanitary authorities in every country should interchange maps, \&c., and that the methods of recording disease should be the same. It is easy to draw up forms for international use. I have given one quotation from Buckle. I shall cunclude with another, as an excuse for not tracing in detail the wav in which diseases have originated or spread:- "To do this would require a learning and a reach of thought to which hardly any single man ou wht to pretend, since it is one thing to have a perception of a large and general truth, and it is another tbiug to follow out the truth in all its ramifications, and prove it by such evidence as will satisfy ordinary readers" - (vol. i.,p. 131).

Hallfax.

THE committee of the Hastings infirmary have just accepted an offir from the Misses Brisco to present to the trustees the large and commodious White Rinck Villa for the purposes of a convalescent home for the infirmary patients.

\section{SOME OBSERVATIONS ON THE CONTAGIOUS} DISEASES ACTS.

BY RAWDON MACNAMARA, F.R.C.S.I.,

SENIOR SURGEON TO THE WESTMIORELAND LOCK (GOVERNMENT) HOSPITAL, DUBLIN.

OF the many burning questions at present agitating our minds, perhaps there is none discussed with greater warmth than the propriety of retaining amongst our statutes the Acts of Parliament known by the name of the "Contagious Diseases Acts." Whether they should be abolished, revained, or even extended is discussed with an amount of energy approaching acrimony, calculated to excite surprise in the calm mind of a philosopher; and yet it strikes me that in all this controversy the question has been almost exclusively approached by those who would wish, not only their continuance, but their extension, from the man's side of the case, to a very great extentignoring that of the woman; whilst the opponents of these measures seem to me to think that any beneficial results that may flow from such enactments are confined to the male sex-on their side also ignoring the woman in the discussion. Whilst at once avowing myself as an uncom promising opponent of the "billet de sante" system-an occupation in my opinion degrading to any respectable surgeon-still I should wish to point ont, from the woman's standpoint of view, why it is that I should wish these Acts not only to be continued, but to be widely extended; and the facts which $I$ shall submit in support of my views cannot be gainsaid-facts which, if called upon to do so, I can support by unquestionable documentary evidence. During the past five years our return of patients admitted into the Lock Hospital would show an average of 700 unfortunates annually admitted. Of these $I$ am in a position to prove that $5 \mathrm{ll}$ were reclaimed-something like one out of every seven saved from a life of sin !-225 sent to asylums, 88 reconciled and restored to their parents, 50 sent to the poorhouses, and 148 provided with respectable situations. All this gond work due to the fact that their admission into the hospital brought them under the direct pious mini-trations of our chaplains, the Rev. Dr. Gibson and the Very Rev. Canon Forde, whose exhortations, ably aided by our Matron, Mrs. Hogan, bore this good fruit. It would be but to abuse the patience of my readers were I to point out how inaccessible to such influences would have been these poor sinners were there no such hospital for their reception; and it is a matter for legitimate speculation how many more might have been rescued were the Acts compulsory, thereby bringing a larger number und $\mathrm{r}$ such influences.

So far I have been considering the subject from its moral aspect. I should desire now to say a few words upon the physical side of the case. How often have I wished when admitting these unfortunates into my hospital that some of the most earne st of the opponents of the Cuntagions Diseases Acts could be present to judge for themselves the amount of suffering they would iuflict upon an erring sister by permitting her to ply her trade at a period when to do so must have been pre-ent torture and future misery. How often has the question been as it were wrenched trom me, "My poor girl, why have you not applied ere this?" No one in general practice and unconnected with a Lock hospital can have any idea of the fedrful condition in which from time to time patients are admitted into my hospital, which is situated in a city unfortunately not under the Contagious Diseases Act;. Were these Acts in force in Dublin, it would be simply impossible for such harrowing cases to present themselres. As it is, patients rarely present themselves in the earlier stages of therr direase, when their treatment is manifeatly more amenable. The effect of this on our general population, and more especially upon our garrison, it is unvecessary for me to point out.

Dublin.

Presentation. - Dr. Robert Jones, who has filled the office of A:sistant Medical Officer at Earlswood Asy lum for two years, and has just been appointed to a similar position at Colney Hatch Asylum, has been presented bv the Earlswood staff with a very handsome timepiece and illuminated address as a mark of their high esteem and regard. 